\title{
A STUDY ON CUSTOMERS PREFERENCES AND SATISFACTION TOWARDS MODERN BANKING SERVICES OF SELECT PUBLIC SECTOR BANKS IN KANYAKUMARI DISTRICT
}

\author{
MR. P. GODWIN PRINCE ${ }^{1}$, DR. A. MAHALINGAM ${ }^{2} \&$ DR. C. THILAGAM ${ }^{3}$ \\ ${ }^{1}$ Ph.D Research Scholar in Commerce-Part Time Internal, Manonmaniam Sundaranar University, Abishekapatti, Tirunelveli, \\ India \\ ${ }^{2}$ Guide, Department of Commerce, Manonmaniam Sundaranar University, Abishekapatti, Tirunelveli, India \\ ${ }^{3}$ Co-Guide, Department of Commerce, Manonmaniam Sundaranar University, Abishekapatti, India
}

\begin{abstract}
This study explores and examines some important elements that help in consumers' preference towards modern banking services of public sector banks. Banker should understand the need of customer so that they can improve the insufficient of the services. Banker should find out the way to attract more customers to utilize their services. In this regard a study has been undertaken in modern banking services provided by the public sector banks in Kanyakumari district. The present study evaluates the preference of customers with regard to modern banking services provided by public sector banks in Kanyakumari district. The study focuses on examining various factors taken into consideration while dealing with the different modern banking services rendered by public sector banks. The respondents were further asked to give their responses on a measurement scale of five varying from very satisfied to very dissatisfied. Total 450 customers from public sector banks were randomly selected in Kanyakumari district. The study embodied both secondary and primary data. Primary data has been collected through the questionnaire and also by observations and interviews taken from the respondents personally. The study is also supported by secondary data, which has been sought from various reference books, journals, magazines, newspapers and Internet etc. The researcher has found that the most of the customers in and around
\end{abstract} Kanyakumari district were aware of the modern banking services offered by the public sector banks.

KEYWORDS: Modern Banking Services, Debit Card, Credit Card and Satisfaction

Received: Feb 06, 2020; Accepted: Feb 26, 2020; Published: Nov 23, 2020; Paper Id.: IJMPERDFEB202090

\section{INTRODUCTION}

At the beginning of the 21st century, banks across the world have become complex financial organizations that offered a wide variety of services to international markets. Supported by technology, banks are working to identify new business places, to develop customized services, to implement innovative strategies and to capture new market opportunities. The tremendous advances in technology and the aggressive infusion of information technology had brought in a paradigm shift in banking operations. For the banks, technology has emerged as a strategic resource for achieving higher efficiency, control of operations, productivity and profitability. This has instigated the banks to take-up technology to meet the increasing customer satisfaction and to face stiff competition. Therefore, Indian banks now have to develop modern banking services with world class service standards for satisfying their customers. 


\section{Statement of the Problem}

This study explores and examines some important elements that help in consumers' preference towards modern banking services of public sector banks. Banker should understand the need of customer so that they can improve the insufficient of the services. Banker should find out the way to attract more customers to utilize their services. In line with global trends, most customers are not focusing on this internet application. In order to solve this problem customer should learn to use internet banking which can bring conveniences without going to the bank. On the other hand, there are few factors that lead to this problem occurrence. Many people don't start to use e-banking because they still not trust on the system through internet. In addition there are few cases of fraud have been reported in online banking. Secondly, there are lacks of social contact because while performing transactions through e-banking the customer doesn't get any assistance from the banker. In this regard a study has been undertaken in modern banking services provided by the public sector banks in Kanyakumari district.

\section{OBJECTIVES OF THE STUDY}

The study has the following objectives.

- To study the preference of customers towards modern banking services of public sector banks in Kanyakumari district.

- To analyze the satisfaction level of customers towards modern banking services provided by the public sector banks in Kanyakumari district.

\section{METHODOLOGY}

The present study evaluates the preference of customers with regard to modern banking services provided by public sector banks in Kanyakumari district. The study focuses on examining various factors taken into consideration while dealing with the different modern banking services rendered by public sector banks. The respondents were further asked to give their responses on a measurement scale of five varying from very satisfied to very dissatisfied. Total 450 customers from public sector banks were randomly selected in Kanyakumari district. The study embodied both secondary and primary data. Primary data has been collected through the questionnaire and also by observations and interviews taken from the respondents personally. The study is also supported by secondary data, which has been sought from various reference books, journals, magazines, newspapers and Internet etc.

\section{Analysis and Interpretation}

Table 1: Classification of Sample Respondents according to level of satisfaction over modern banking facilities

\begin{tabular}{|c|c|c|c|c|c|c|}
\hline SI. No & $\begin{array}{c}\text { Modern banking } \\
\text { service }\end{array}$ & $\begin{array}{c}\text { Highly } \\
\text { satisfied }\end{array}$ & Satisfied & Neutral & Dissatisfied & $\begin{array}{c}\text { Highly } \\
\text { dissatisfied }\end{array}$ \\
\hline 1. & Cash Withdrawal & $\begin{array}{l}61 \\
(13.6 \%)\end{array}$ & $\begin{array}{l}160 \\
(35.6 \%)\end{array}$ & $\begin{array}{l}173 \\
(38.4 \%)\end{array}$ & $\begin{array}{l}39 \\
(8.7 \%)\end{array}$ & $\begin{array}{l}17 \\
(3.8 \%)\end{array}$ \\
\hline 2. & $\begin{array}{ll}\text { Account } & \text { Balance } \\
\text { Enquiry } & \\
\end{array}$ & $\begin{array}{l}24 \\
(5.3 \%)\end{array}$ & $\begin{array}{l}124 \\
(27.6 \%)\end{array}$ & $\begin{array}{l}159 \\
(35.3 \%) \\
\end{array}$ & $\begin{array}{l}93 \\
(20.7 \%) \\
\end{array}$ & $\begin{array}{l}50 \\
(11.1 \%) \\
\end{array}$ \\
\hline 3. & $\begin{array}{l}\text { Request for Cheque } \\
\text { Book }\end{array}$ & $\begin{array}{l}16 \\
(3.6 \%)\end{array}$ & $\begin{array}{l}144 \\
(32.0 \%)\end{array}$ & $\begin{array}{l}143 \\
(31.8 \%)\end{array}$ & $\begin{array}{l}81 \\
(18.0 \%)\end{array}$ & $\begin{array}{l}66 \\
(14.7 \%)\end{array}$ \\
\hline 4. & Transfer of fund & $\begin{array}{l}91 \\
(20.2 \%)\end{array}$ & $\begin{array}{l}166 \\
(36.9 \%)\end{array}$ & $\begin{array}{l}131 \\
(29.1 \%)\end{array}$ & $\begin{array}{l}44 \\
(9.8 \%)\end{array}$ & $\begin{array}{l}18 \\
(4.0 \%)\end{array}$ \\
\hline 5. & Bill payment & 98 & 134 & 133 & 57 & 28 \\
\hline
\end{tabular}



Services of Select Public Sector Banks in Kanyakumari District

\begin{tabular}{|l|l|l|l|l|l|l|}
\hline & & $(21.8 \%)$ & $(\mathbf{2 9 . 8} \%)$ & $(29.6 \%)$ & $(12.7 \%)$ & $(6.2 \%)$ \\
\hline 6. & $\begin{array}{l}\text { Deposit Cash or } \\
\text { Cheques }\end{array}$ & $\begin{array}{l}66 \\
(14.7 \%)\end{array}$ & $\begin{array}{l}126 \\
(28.0 \%)\end{array}$ & $\begin{array}{l}\mathbf{1 7 8} \\
\mathbf{( 3 9 . 6 \% )}\end{array}$ & $\begin{array}{l}57 \\
(12.7 \%)\end{array}$ & $\begin{array}{l}23 \\
(5.1 \%)\end{array}$ \\
\hline 7. & Mini Statement & 81 & 127 & $\mathbf{1 8 0}$ & 53 & 9 \\
& & $(18.0 \%)$ & $(28.2 \%)$ & $\mathbf{4 0 . 0} \%)$ & $(11.8 \%)$ & $(2.0 \%)$ \\
\hline & Total & $\mathbf{4 5 0}$ & $\mathbf{4 5 0}$ & $\mathbf{4 5 0}$ & $\mathbf{4 5 0}$ & $\mathbf{4 5 0}$ \\
\hline
\end{tabular}

Source: Primary data

Table 1 shows that regarding Cash withdrawal service $38.4 \%$ of the respondents feel a Neutral level of satisfaction and $35.6 \%$ of the respondents are satisfied, regarding Account balance enquiry 35.3\% of the respondents feel Neutral level of satisfaction, regarding Request for cheque book online 32.0\% of the respondents feel Satisfied, Regarding electronic fund transfer (ETFs) $36.9 \%$ of the respondents feel satisfied, $29.8 \%$ of the respondents feel satisfied with Utility bills payment service, $39.6 \%$ of the respondents feel Neutral with Cash and cheque deposits and $40.0 \%$ of the respondents feel Neutral with Mini statement request. It is inferred that by overall respondents have a positive level of satisfaction towards the modern banking facilities in the study area.

\section{Preference towards the features of Credit Card among different age group of customers}

An attempt has been made to find out the significant difference in preference towards the features of credit card among different age group of customers, 'ANOVA' test is used with the null hypothesis as, "There is no significant difference in preference towards the features of credit card among different age group of customers in Kanyakumari District". The result of 'ANOVA' test for preference towards the features of credit card among different age group of customers is presented in Table 2 .

Table 2: Preference towards the features of Credit Card among different age group of customers

\begin{tabular}{|c|c|c|c|c|c|c|c|}
\hline \multirow[t]{2}{*}{ Features of credit card } & \multicolumn{6}{|c|}{ Age Group (Mean Score) } & \multirow[t]{2}{*}{ F Statistics } \\
\hline & $\begin{array}{c}\text { Below } \\
20 \\
\text { years }\end{array}$ & $\begin{array}{l}20-30 \\
\text { years }\end{array}$ & $\begin{array}{l}31-40 \\
\text { years }\end{array}$ & $\begin{array}{l}\text { 41-50 } \\
\text { years }\end{array}$ & $\begin{array}{l}51-60 \\
\text { years }\end{array}$ & $\begin{array}{c}\text { Above } 60 \\
\text { years }\end{array}$ & \\
\hline Enough repayment period & 3.4286 & 3.5281 & 3.6000 & 3.7227 & 3.6578 & 3.5217 & 0.197 \\
\hline $\begin{array}{l}\text { Cash back bonus for timely } \\
\text { repayment }\end{array}$ & 4.2557 & 4.1342 & 4.0526 & 4.0682 & 4.2800 & 4.2174 & 0.360 \\
\hline Low rate of interest & 3.7143 & 3.5026 & 3.4421 & 3.5455 & 3.6400 & 3.5652 & 0.533 \\
\hline Low credit card charge & 4.0000 & 3.8243 & 3.8947 & 3.8636 & 4.0400 & 4.3043 & 1.710 \\
\hline Balance transfer interest rate & 3.8571 & 4.1118 & 4.1316 & 4.2500 & 4.3600 & 4.3478 & 0.982 \\
\hline $\begin{array}{l}\text { EMI conversion for debit } \\
\text { amount }\end{array}$ & 4.0525 & 3.6581 & 3.6579 & 3.7955 & 3.9200 & 3.6859 & 1.038 \\
\hline Flexible repayment dates & 4.2857 & 3.6837 & 4.1842 & 3.8409 & 4.0000 & 3.7391 & $2.575^{*}$ \\
\hline Security of transactions & 3.7543 & 3.9904 & 3.9737 & 4.1364 & 4.0800 & 4.4783 & 1.646 \\
\hline
\end{tabular}

\section{Source: Primary data}

*-Significant at five per cent level

It is understood from the Table 2 that flexible repayment dates and cash back bonus for timely repayment are the important preference towards the features of credit card among the customers who belong to the age group of below 20 years as their mean scores are 4.2857 and 4.2557 respectively. It is further understood that cash back bonus for timely repayment and balance transfer interest rate are the important preference towards the features of credit card among the customers who belong to the age group between 20-30 years as their mean scores are 4.1342 and 4.1118 respectively. Table further shows that flexible repayment dates and balance transfer interest rate are the important preference towards 
the features of credit card among the customers who belong to the age group between 31-40 years as their mean scores are 4.1842 and 4.1316 respectively. Table further reveals that balance transfer interest rate and security of transactions are the important preference towards the features of credit card among the customers who belong to the age group between 41-50 years as their mean scores are 4.2500 and 4.1364 respectively. Table further highlights that balance transfer interest rate and cash back bonus for timely repayment are the important preference towards the features of credit card among the customers who belong to the age group between 51-60 years as their mean scores are 4.3600 and 4.2800 respectively. Table further reveals that security of transactions and balance transfer interest rate are the important preference towards the features of credit card among the customers who belong to the age group of above 60 years as their mean scores are 4.4783 and 4.3478 respectively. Regarding the preference towards the features of credit card among different age group of customers, flexible repayment dates is statistically significant at 5 per cent level.

\section{Preference towards the features of Debit Card among different gender group of customers}

In order to find out the significant difference in preference towards the features of debit card among different gender group of customers, ' $\mathrm{t}$ ' test is used with the null hypothesis as, "There is no significant difference in preference towards the features of debit card among different gender group of customers in Kanyakumari District". The result of ' $t$ ' test for preference towards the features of debit card among different gender group of customers is presented in Table 3.

Table 3: Preference towards the features of Debit Card among different Gender group of customers

\begin{tabular}{|l|c|c|c|}
\hline \multicolumn{1}{|c|}{ Features of Debit Card } & \multicolumn{2}{c|}{ Gender [Mean Score] } & \multirow{2}{*}{ t Statistics } \\
\cline { 2 - 3 } & Male & Female & \\
\hline Easy to obtain a debit card & 4.3591 & 4.4519 & 0.251 \\
\hline Limited to the existing funds in the account & 3.3356 & 3.4221 & 0.229 \\
\hline Use of debit card for online shopping & 3.4564 & 3.5017 & 0.440 \\
\hline Affiliated debit card used by the family members & 3.6174 & 3.6912 & 0.141 \\
\hline
\end{tabular}

\section{Source: Primary data}

*-Significant at five per cent level

From the above table, it is understood that easy to obtain a debit card and affiliated debit card used by the family members are the important preference towards the features of debit card among the male customers as their mean scores are 4.3591 and 3.6174 respectively. It is further understood that easy to obtain a debit card and affiliated debit card used by the family members are the important preference towards the features of debit card among the female customers as their mean scores are 4.4519 and 3.6912 respectively. Regarding the preference towards the features of debit card among different gender group of customers, easy to obtain a debit card, limited to the existing funds in the account, use of debit card for online shopping and affiliated debit card used by the family members are not statistically significant at 5 per cent level.

\section{Preference towards the features of internet banking services among different marital status of customers}

In order to find out the significant difference in preference towards the features of internet banking services among different marital status of customers, ' $t$ ' test is used with the null hypothesis as, "There is no significant difference in preference towards the features of internet banking services among different marital status of customers in Kanyakumari District". The result of ' $\mathrm{t}$ ' test for preference towards the features of internet banking services among different marital status of customers is presented in Table 4. 
Table 4: Preference towards the features of internet banking services among different Marital Status of customers

\begin{tabular}{|l|c|c|c|}
\hline \multicolumn{1}{|c|}{ Features of internet banking services } & \multicolumn{2}{c|}{$\begin{array}{c}\text { Marital Status } \\
\text { [Mean Score] }\end{array}$} & t Statistics \\
\cline { 2 - 3 } & Married & Unmarried & \\
\hline Check balances online & 3.4796 & 3.6619 & 1.778 \\
\hline E-Ticketing with the banks & 3.4082 & 3.7386 & $2.908^{*}$ \\
\hline Online Shopping through internet banking & 3.4286 & 3.6023 & 1.538 \\
\hline Apply and manage credit cards online & 3.6539 & 3.7502 & 0.144 \\
\hline Prepaid mobile recharge & 3.5510 & 3.3807 & 1.367 \\
\hline Product and rate information & 4.0102 & 3.8807 & 1.057 \\
\hline Update personal profile & 3.7955 & 3.7230 & 0.358 \\
\hline Online bill payments & 3.9082 & 3.7983 & 0.894 \\
\hline Download previous transaction history & 3.8776 & 3.8693 & 1.066 \\
\hline Apply for customer loan & 4.0306 & 3.9545 & 0.675 \\
\hline Download application forms & 4.0563 & 3.9375 & 0.788 \\
\hline Inter - accounts transfer & 4.1122 & 4.0426 & 0.615 \\
\hline EMI calculation for loan & 4.0918 & 3.9631 & 1.093 \\
\hline
\end{tabular}

\section{Source: Primary data}

*-Significant at five per cent level

Table 4 indicates that inter - accounts transfer and EMI calculation for loan are the important preference towards the features of internet banking services among the married customers as their mean scores are 4.1122 and 4.0918 respectively. It is further understood that inter - accounts transfer and EMI calculation for loan are the important preference towards the features of internet banking services among the unmarried customers as their mean scores are 4.0426 and 3.9631 respectively. Regarding the preference towards the features of internet banking services among different marital status of customers, E-Ticketing with the banks is statistically significant at 5 per cent level.

\section{Preference towards the features of Mobile Banking among different gender group of customers}

In order to find out the significant difference in preference towards the features of mobile banking among different gender group of customers, ' $t$ ' test is used with the null hypothesis as, "There is no significant difference in preference towards the features of mobile banking among different gender group of customers in Kanyakumari District". The result of ' $t$ ' test for preference towards the features of mobile banking among different gender group of customers is presented in Table 5.

Table 5: Preference towards the features of Mobile banking among different Gender group of customers

\begin{tabular}{|l|c|c|c|}
\hline \multicolumn{1}{|c|}{ Features of Mobile Banking } & \multicolumn{2}{c|}{ Gender [Mean Score] } & \multirow{2}{*}{ t Statistics } \\
\cline { 2 - 4 } & Male & Female & \\
\hline Balance enquiry & 4.0671 & 3.9369 & 1.384 \\
\hline Cheque status enquiry & 4.0403 & 3.8173 & $2.118^{*}$ \\
\hline Stop cheque request & 4.1096 & 4.0470 & $2.205^{*}$ \\
\hline Cheque book request & 4.1196 & 4.0075 & $2.477^{*}$ \\
\hline Make payments for the bills & 4.1960 & 4.1007 & $2.581^{*}$ \\
\hline Due date remainder for loans & 3.8926 & 3.8472 & 0.451 \\
\hline Interactive voice request & 3.8904 & 3.8256 & 0.247 \\
\hline Request for renewal of fixed deposits & 3.9060 & 3.8172 & 0.767 \\
\hline Request for new schemes through SMS & 3.9530 & 3.8372 & 1.086 \\
\hline
\end{tabular}

\section{Source: Primary data}

*-Significant at five per cent level 
From the above table 5, it is understood that make payments for the bills and cheque book request are the important preference towards the features of mobile banking among the male customers as their mean scores are 4.1960 and 4.1196 respectively. It is further understood that make payments for the bills and stop cheque request are the important preference towards the features of mobile banking among the female customers as their mean scores are 4.1007 and 4.0470 respectively. Regarding the preference towards the features of mobile banking among different gender group of customers, cheque status enquiry, stop cheque request, cheque book request and make payments for the bills are statistically significant at 5 per cent level.

\section{Preference towards the features of Electronic Clearing Services among different age group of customers}

An attempt has been made to find out the significant difference in preference towards the features of electronic clearing services among different age group of customers, 'ANOVA' test is used with the null hypothesis as, "There is no significant difference in preference towards the features of electronic clearing services among different age group of customers in Kanyakumari District". The result of 'ANOVA' test for preference towards the features of electronic clearing services among different age group of customers is presented in Table 6.

Table 6: Preference towards the features of electronic clearing services among different age group of customers

\begin{tabular}{|c|c|c|c|c|c|c|c|}
\hline \multirow{2}{*}{$\begin{array}{l}\text { Features of electronic } \\
\text { clearing services }\end{array}$} & \multicolumn{6}{|c|}{ Age Group (Mean Score) } & \multirow[t]{2}{*}{ F Statistics } \\
\hline & $\begin{array}{c}\text { Below } \\
20 \\
\text { years }\end{array}$ & $\begin{array}{l}20-30 \\
\text { years }\end{array}$ & $\begin{array}{l}31-40 \\
\text { years }\end{array}$ & $\begin{array}{l}41-50 \\
\text { years }\end{array}$ & $\begin{array}{l}51-60 \\
\text { years }\end{array}$ & $\begin{array}{c}\text { Above } 60 \\
\text { years }\end{array}$ & \\
\hline $\begin{array}{l}\text { ECS-Credit helps fast } \\
\text { payment of } \\
\text { interest/dividend to the } \\
\text { shareholders }\end{array}$ & 3.7143 & 3.7391 & 3.9265 & 3.9600 & 4.2368 & 4.3182 & $2.760^{*}$ \\
\hline $\begin{array}{l}\text { ECS-Credit is very popular } \\
\text { for crediting salaries and } \\
\text { pension }\end{array}$ & 3.7826 & 3.8498 & 3.8771 & 4.0000 & 4.1000 & 4.1909 & 0.593 \\
\hline $\begin{array}{l}\text { ECS-Credit used for vender } \\
\text { payment }\end{array}$ & 4.0000 & 4.0789 & 4.0831 & 4.1009 & 4.0435 & 4.2400 & 1.109 \\
\hline $\begin{array}{l}\text { ECS-Credit used for } \\
\text { payment of cheques }\end{array}$ & 4.0500 & 4.0800 & 4.0789 & 4.0910 & 4.0977 & 4.2174 & 0.982 \\
\hline $\begin{array}{l}\text { ECS-Credit used for } \\
\text { payment of bills }\end{array}$ & 4.1364 & 4.1429 & 4.1629 & 4.1600 & 4.1842 & 4.2644 & 0.170 \\
\hline $\begin{array}{l}\text { ECS-debit helps fast } \\
\text { collection of bills }\end{array}$ & 3.4286 & 3.6000 & 3.8339 & 4.0000 & 3.8969 & 4.1316 & 1.189 \\
\hline $\begin{array}{l}\text { ECS-debit used for } \\
\text { collection of insurance } \\
\text { premium }\end{array}$ & 3.7143 & 3.8051 & 3.9600 & 4.0545 & 4.0227 & 4.0435 & 0.802 \\
\hline $\begin{array}{l}\text { ECS-debit helps to recharge } \\
\text { mobile phone }\end{array}$ & 3.6800 & 3.7391 & 3.8421 & 3.8571 & 3.8690 & 3.9591 & 0.239 \\
\hline $\begin{array}{l}\text { ECS-debit used for } \\
\text { collection of cheques }\end{array}$ & 3.6400 & 3.7045 & 3.7243 & 3.8946 & 3.9130 & 4.0789 & 0.805 \\
\hline $\begin{array}{l}\text { ECS-debit used for } \\
\text { collection of periodical } \\
\text { installments }\end{array}$ & 3.7546 & 3.7986 & 3.8241 & 3.8469 & 3.8759 & 3.9029 & 1.215 \\
\hline
\end{tabular}

\section{Source: Primary data}

*-Significant at five per cent level

From the above table 6, it is understood that ECS-Credit used for payment of bills and ECS-Credit used for payment of cheques are the important preference towards the features of electronic clearing services among the customers 
who belong to the age group of below 20 years as their mean scores are 4.1364 and 4.0500 respectively. It is further understood that ECS-Credit used for payment of bills and ECS-Credit used for payment of cheques are the important preference towards the features of electronic clearing services among the customers who belong to the age group between 20-30 years as their mean scores are 4.1429 and 4.0800 respectively. Table further shows that ECS-Credit used for payment of bills and ECS-Credit used for vender payment are the important preference towards the features of electronic clearing services among the customers who belong to the age group between 31-40 years as their mean scores are 4.1629 and 4.0831 respectively. Table further reveals that ECS-Credit used for payment of bills and ECS-Credit used for vender payment are the important preference towards the features of electronic clearing services among the customers who belong to the age group between 41-50 years as their mean scores are 4.1600 and 4.1009 respectively. Table further highlights that ECS-Credit helps fast payment of interest/dividend to the shareholders and ECS-Credit used for payment of bills are the important preference towards the features of electronic clearing services among the customers who belong to the age group between 51-60 years as their mean scores are 4.2368 and 4.1842 respectively. Table further reveals that ECS-Credit helps fast payment of interest/dividend to the shareholders and ECS-Credit used for payment of bills are the important preference towards the features of electronic clearing services among the customers who belong to the age group of above 60 years as their mean scores are 4.3182 and 4.2644 respectively. Regarding the preference towards the features of electronic clearing services among different age group of customers, ECS-Credit helps fast payment of interest/dividend to the shareholders is statistically significant at 5 per cent level.

\section{SUGGESTIONS}

- As a majority of the respondents are uncomfortable in using mobile devices for banking purpose, the banks should form a separate department in the bank itself to take care of the mobile banking services.

- The public sector banks must update the customer friendly innovative technologies to offer modern banking services effectively and it will definitely increase the level of satisfaction of the customers.

- To increase the customers level of satisfaction towards the payment through the ATMs, the banks must make effective changes in their technological set up to ensure safety and availability of data related to the payments.

- The bank must provide relevant facts about their information technology based services to create awareness among the customers.

- Another aspect was, customers have to understand fully about the major benefits and its usefulness of modern banking services. They have to be very clear in safety and security aspects. Hence, it was the duty of the banks or financial institutions to inculcate the knowledge of online services to the relevant customers.

- The banks should spread awareness by providing training about the use of self-service machines and e-banking services among customers.

- The number of machines installed should be increased in all areas to meet customer needs and requirements.

\section{CONCLUSIONS}

The researcher has found that the most of the customers in and around Kanyakumari district were aware of the modern banking services offered by the public sector banks. They need not waste much time in a queue and can carry out the transactions within the short span of time. Overall, it enhances that the customers had a positive impact towards the modern banking services offered in Kanyakumari district. The public sector banks provides many modern banking services 
throughout the country. The customers are the strong pillars supporting the services in any field and the ultimate cause of its success. Therefore, public sector banks has to concentrate to widen its customers base to strengthen its activities and achieve success through them by true, sincere and excellent services.

\section{REFERENCES}

1. Ramanigopal (2011). Customer Perception towards Internet Banking Services with Special Reference to Erode District. Asian Journal of Business and Economics, Vol.1, No.1, pp.1-17.

2. Rameesha Kalra (2019). Beyond the branch: A Study of Innovative Practices in Banking Services in India. Journal of Emerging Technologies and Innovative Research (JETIR), Vol.6, Issue.1, pp.664-674

3. Ramola Premalatha (2015). Adoption of Internet Banking in Tamil Nadu, India. The International Journal of Social Sciences and Humanities Invention, Vol.2, Issue.01, pp.1073-1089

4. Ranjan J Sabhaya (2014). Study on Pre and Post Impact of E-Banking on Banking Operation. GALAXY International Interdisciplinary Research Journal, Vol.2, No.3, pp.175-186.

5. Renugadevi (2013). A Study on Customer's Attitude Towards E-Banking in Madurai City. International Journal of scientific research and management (IJSRM), Special Issue on e-Marketing Road Ahead of India, pp.01-05. 